\title{
Assessment of Digital Maturity of Agricultural Enterprises
}

\author{
N.A. Safiullin ${ }^{1, *}, A . Y u$. Mironkina ${ }^{2}$, S.S. Kharitonov ${ }^{3}$, E.V. Trofimenkova ${ }^{4}$ and T.P. Shevtsova ${ }^{5}$ \\ ${ }^{1}$ Kazan State Agrarian University, Russia \\ ${ }^{2}$ Smolensk State Agricultural Academy, Russia \\ ${ }^{3}$ All-Russian Research Institute of Phytopathology, Russia \\ ${ }^{4}$ Vladivostok State University of Economics and Service, Russia \\ ${ }^{5}$ Smolensk State University, Russia
}

\begin{abstract}
The article substantiates the need to assess the readiness of agricultural organizations for digital transformation. The main stages of creation of a unified national agricultural platform are described. The main directions for assessing digital maturity are analyzed. Typical problems of agricultural enterprises in the digitalization of business processes are identified. The aim of the study was to develop a method for assessing the digital maturity of an agricultural enterprise using a questionnaire. It was proposed to use the final assessment of digital maturity as the main indicator of readiness of agricultural enterprises for digital transformation. Based on the comparison with the target indicator of digital maturity, the article suggests setting a level of readiness for digital transformation. The authors conducted a study of the Niva agricultural company located in Rudnyansk district, Smolensk region.
\end{abstract}

\section{Introduction}

The digital transformation of agricultural enterprises through digital technologies and platform solutions is the main factor of their performance and productivity. According to the departmental project "Digital Agriculture", it is planned to create a single national platform in the agro-industrial complex of the Russian Federation by 2024. [1]

This project involves the phased introduction of certain elements of digitalization of agricultural enterprises. At the initial stage, it is planned to create a digital platform for the state regulation of agriculture. This will allow for collecting, processing and using data for effective interaction between executive authorities and agricultural enterprises. It is planned to create and implement the digital module "AgroSolutions", which can help manufacturers to double the productivity of employees. The final stage is development of a training system for agricultural enterprises that will have required competencies in the digital economy. Thus, the digital environment is fundamentally changing the nature of markets and competition, creating new opportunities and threats [5].

The central elements of the digitalization are agricultural enterprises that must undergo digital transformation. Digital transformation is the reengineering of basic processes of an organization using digital tools and changing the business environment. The digital transformation of agricultural organizations should begin with an assessment of the readiness for digitalization or with an assessment of digital maturity. Digital maturity is the ability of an organization to change an information technology-based business operating model.

\section{Materials and methods}

Digital Maturity Assessment is a complex and multilevel study of the enterprise that can determine the potential for digital transformation and develop a strategy for its implementation. Agricultural enterprises differ in scale and specialization; therefore, it becomes necessary to identify individual criteria for assessing digital maturity. However, there are generally accepted directions for assessing the digital maturity of commercial organizations. [2] (Figure 1).

Assessment of infrastructure and tools is aimed at measuring the degree of access to modern digital data analytics tools, which are necessary for the digital transformation. This can involve the use of artificial intelligence technologies, the Internet of things, "big data", etc. [10], as well as receiving services using information and telecommunication technologies, including the portal of state and municipal services [8].

Currently, agricultural enterprises partially use these opportunities, implementing technologies situationally and in pilot sectors. There is a serious problem of the digital divide between large agricultural organizations, which have the potential for implementing digital tools, and small agricultural producers who have limited resources. This aggravates their lag and increases the risk of bankruptcy and market monopolization.

\footnotetext{
* Corresponding author: nsafiullin@outlook.com
} 


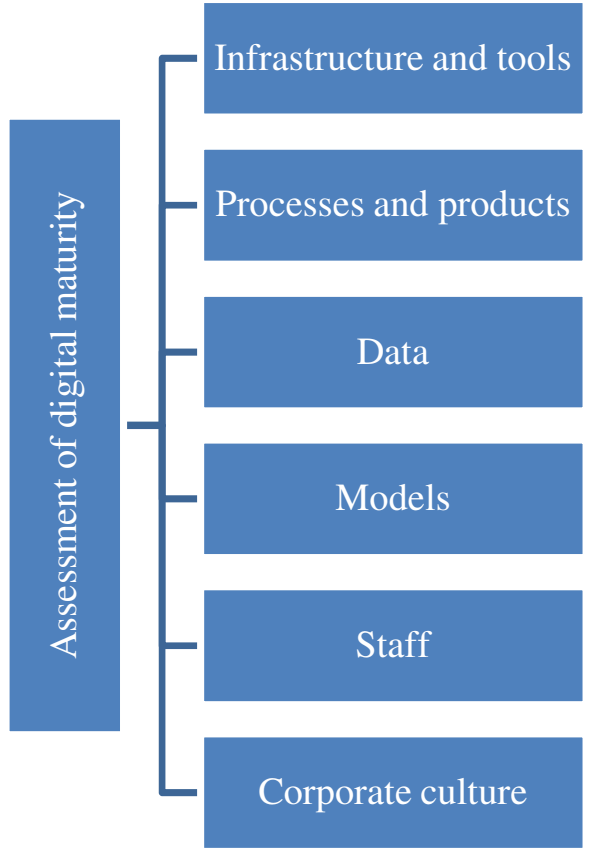

Fig. 1. Key areas for assessing digital maturity

The study of processes and products involves the study of existing business processes, management systems and the readiness for changes in within the planned digital transformation. Agricultural organizations usually have a traditional management model that is difficult to change. It is difficult to restructure the management system. In addition, the schemes for the sale of agricultural products include many intermediaries which strive to maintain their current positions, since the digital transformation of agricultural enterprises will make it possible to get rid of many unnecessary elements.

Studying the ways of storing information, the speed of access to it and possibilities of data processing are important stages in assessing the digital maturity of agricultural enterprises. In rural areas, many agricultural organizations are experiencing difficulties with the spread of the Internet and the speed of Internet access. Not all manufacturers are ready to invest in technical support; many small enterprises store of information in paper form. This is facilitated by the lack of digital skills in employees.

Evaluation of the information transfer and data processing models involves the study of data analytics methods, the level of use of digital technologies. Currently, most agricultural organizations use descriptive analytics, which involves the comparison of economic performance with historical periods. There are a number of large agricultural enterprises that use statistical techniques such as regression analysis or correlation models. A very small number of agricultural organizations use predictive or prescriptive analytics based on the artificial intelligence technologies.

The study of the staff potential involves the assessment of competencies in the context of the digital environment. Digital inequality and a low level of digital literacy affect the willingness of agricultural personnel to master new technologies and tools for transferring knowledge to colleagues. According to research, the rural population is less provided with access to the Internet [9]. The seasonal nature of rural labor, its irregularity and complexity does not allow employees to improve their digital skills, which causes the lag of agricultural organizations in the digital transformation.

Table 1. Questionnaire of employees and managers to identify the degree of digital maturity of an agricultural enterprise

\begin{tabular}{|c|c|c|}
\hline & $\begin{array}{c}\text { Current } \\
\text { indicator }\end{array}$ & \begin{tabular}{|c|} 
Target \\
indicator
\end{tabular} \\
\hline \multicolumn{3}{|c|}{ Block 1. Infrastructure and tools } \\
\hline $\begin{array}{l}\text { Assess the level of use of information } \\
\text { technology }\end{array}$ & & 3 \\
\hline Assess the level of use of digital services & & 3 \\
\hline Assess the level of costs for digitalization & & 3 \\
\hline \begin{tabular}{|c|} 
Total scores in block 1 \\
\end{tabular} & & 9 \\
\hline \multicolumn{3}{|l|}{ Block 2. Business processes } \\
\hline $\begin{array}{l}\text { Assess the level of flexibility of the } \\
\text { organizational structure }\end{array}$ & & 3 \\
\hline $\begin{array}{l}\text { Assess the degree of process } \\
\text { management }\end{array}$ & & 3 \\
\hline $\begin{array}{c}\text { Assess the level of automation of } \\
\text { processes }\end{array}$ & & 3 \\
\hline Total scores in block 2 & & 9 \\
\hline \multicolumn{3}{|l|}{ Block 3. Data } \\
\hline Assess the data collection mechanism & & 3 \\
\hline $\begin{array}{l}\text { Assess the degree of technical support } \\
\text { for data processing }\end{array}$ & & 3 \\
\hline Assess storage engine & & 3 \\
\hline Total scores in block 3 & & 9 \\
\hline \multicolumn{3}{|l|}{ Block 4. Models } \\
\hline Assess the use of analytical methods & & 3 \\
\hline $\begin{array}{l}\text { Assess the quality of forecasting the } \\
\text { performance }\end{array}$ & & 3 \\
\hline $\begin{array}{c}\text { Assess the degree of using AI } \\
\text { technologies in an information analysis }\end{array}$ & & 3 \\
\hline Total scores in block 4 & & 9 \\
\hline \multicolumn{3}{|l|}{ Block 5. Staff } \\
\hline $\begin{array}{c}\text { Assess the level of digital literacy of } \\
\text { employees }\end{array}$ & & 3 \\
\hline $\begin{array}{c}\begin{array}{c}\text { Assess the level of digital competencies } \\
\text { of managers }\end{array} \\
\end{array}$ & & 3 \\
\hline $\begin{array}{l}\text { Assess the readiness of employees to } \\
\text { improve digital literacy }\end{array}$ & & 3 \\
\hline Total scores in block 5 & & 9 \\
\hline \multicolumn{3}{|l|}{ Block 6. Corporate ulture } \\
\hline $\begin{array}{c}\text { Assess the level of interaction between } \\
\text { employees }\end{array}$ & & 3 \\
\hline $\begin{array}{c}\text { Assess the readiness of employees to } \\
\text { innovatations }\end{array}$ & & 3 \\
\hline $\begin{array}{l}\text { Assess the level of interaction between } \\
\text { employees and the manager }\end{array}$ & & 3 \\
\hline Total scores in block 6 & & 9 \\
\hline $\begin{array}{c}\text { Final assessment of the digital } \\
\text { maturity }\end{array}$ & & 54 \\
\hline Digital maturity level & & $100 \%$ \\
\hline
\end{tabular}

The most important aspect of digitalization processes of agricultural enterprises is development of an effective 
corporate. It is necessary to assess the level of readiness of employees to implement innovations and digital tools, as well as the level of interaction between managers and other employees. Today, in many agricultural organizations, the culture of strength is dominant. It requires employees to be error-free. It is difficult to organize team work, which creates obstacles to the digital transformation process.

To assess the digital maturity of agricultural enterprises, the authors developed a questionnaire, which includes three criteria for assessing the above areas (table 1).

For each question, a score is given, where 0 is the minimum value, and 3 is the maximum; the scores are summed up and compared with the target maximum indicator of digital maturity.

The final score of digital maturity $\left(\mathrm{A}_{\mathrm{dm}}\right)$ is calculated by summing up the scores by blocks.

$$
\mathrm{A}_{\mathrm{dm}}=\mathrm{B} 1+\mathrm{B} 2+\mathrm{B} 3+\mathrm{B} 4+\mathrm{B} 5
$$

The level of digital maturity of an agricultural enterprise shows the degree of readiness for digital transformation and is calculated by formula:

$$
L_{d m}=\frac{0_{d m}}{Ц_{d m}} \cdot 100 \%
$$

where $A_{d m}$ - final assessment of the digital maturity $o$

$\mathrm{T}_{\mathrm{dm}}$ - final target assessment of digital transformation

Depending on the values obtained, each agricultural enterprise can set a ranking for the level of readiness for digital transformation (Figure 2).

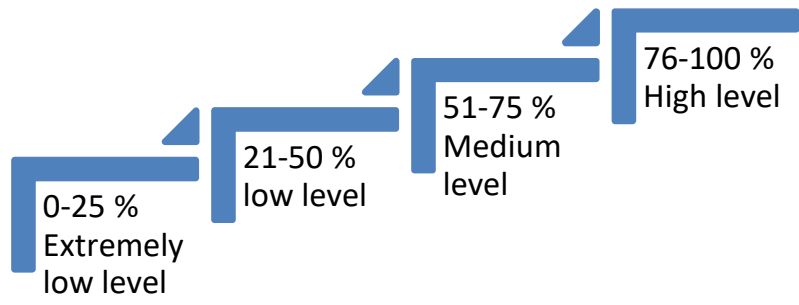

Fig. 2. Levels of readiness of agricultural enterprises for digital transformation

The level of digital maturity allows the managers to assess the potential for digital transformation and identify the main obstacles.

\section{Results}

In Smolensk region, not all farmers are open to the implementation of advanced digital solutions [7]. As an example, the authors studied Niva AC in Rudnyansk district, which has been operating since December 25, 1992. It is located in Sherovichi of Rudnyansk district. According to the Unified Register of Legal Entities, the organization is in the process of reorganization, the main activity is dairy cattle breeding and raw milk production [3]. The activities are presented in Table 2.
Table 2. The volume of agricultural production of Niva AC,

\begin{tabular}{|c|c|c|c|c|c|}
\hline Indicators & 2017 & 2018 & 2019 & 2020 & $\begin{array}{c}2020 \text { to } \\
2017, \%\end{array}$ \\
\hline $\begin{array}{c}\text { The cost of gross } \\
\text { output in current } \\
\text { prices, thousand } \\
\text { rubles }\end{array}$ & 42962 & 40240 & 42293 & 41863 & 97.44 \\
\hline $\begin{array}{c}\text { Cost of } \\
\text { marketable } \\
\text { products in sales } \\
\text { prices, thousand } \\
\text { rubles }\end{array}$ & 27657 & 25015 & 25097 & 22412 & 81.04 \\
\hline $\begin{array}{c}\text { Average annual } \\
\text { number of } \\
\text { employees, people }\end{array}$ & 65 & 59 & 57 & 54 & 83.08 \\
\hline $\begin{array}{l}\text { Average annual } \\
\text { cost of fixed } \\
\text { assets, thousand } \\
\text { rubles }\end{array}$ & 78082 & 80299.5 & $\begin{array}{c}81897 . \\
5\end{array}$ & 82142 & 105.20 \\
\hline $\begin{array}{c}\text { Area of } \\
\text { agricultural land, } \\
\text { ha }\end{array}$ & 2181 & 2181 & 2143 & 2143 & 98.26 \\
\hline incl. arable land & 1507 & 1507 & 1507 & 1507 & 100.00 \\
\hline $\begin{array}{l}\text { Total number of } \\
\text { cattle, heads }\end{array}$ & 631 & 607 & 572 & 545 & 86.37 \\
\hline Including cows & 412 & 375 & 350 & 350 & 84.95 \\
\hline
\end{tabular}
Rudnyansk district, Smolensk region

As can be seen from the presented data, the agricultural enterprise is small. The cost of gross output and marketable output is decreasing. There is an outflow of workers. At the same time, during the period under study, the average annual cost of fixed assets increased by $5.2 \%$. The area of agricultural lands changed slightly, and the number of cattle decreased by $13.6 \%$.

The indicators indicate the need for a deep reorganization of the production processes on the basis of digital tools and technologies.

In March 2021, a survey of the Niva director was conducted. The survey results are presented in the form of a polygon, which shows the main problems that will arise during the digital transformation.

According to the study, the level of digital maturity is $48.1 \%$, which indicates the level of readiness for digital transformation. The main directions for preparing an agricultural enterprise for digitalization are:

1. Reorganization of business processes by implementing a flexible organizational structure based on project management. Organization of digital process management and automation of decision-making processes.

2. Transition from the descriptive to predictive models based on the artificial intelligence technologies.

3. Improving the digital literacy of employees through advanced training courses and development of digital competencies.

4. Implementation of digital services (IoT [10], cloud storage technologies, electronic interaction with executive authorities, etc.) by increasing the for digitalization. 


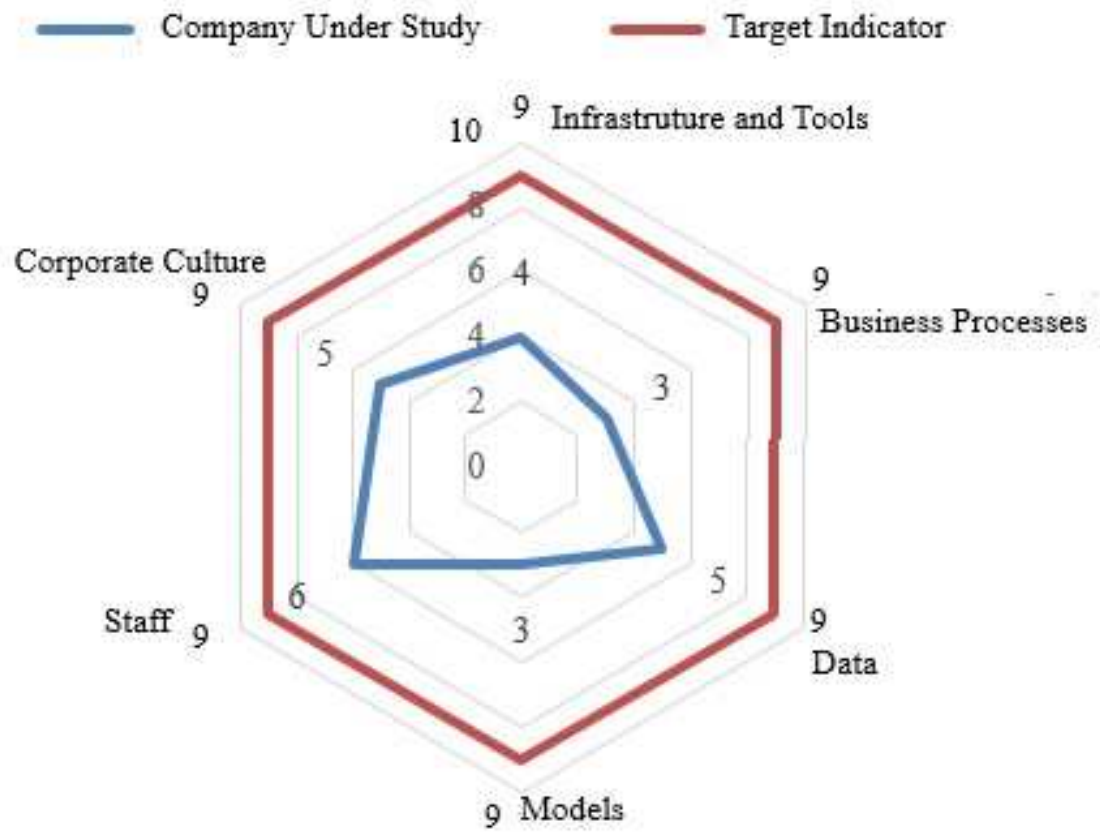

Fig. 3. Assessment of digital maturity of Niva AC, Rudnyansk district, Smolensk region

\section{Conclusion}

Currently, the use of digital technologies is a key factor in the effective development of agriculture [6]. The presented methodology for assessing the digital maturity of agricultural enterprises allows us to identify the main barriers that impede the effective digital transformation. The survey of employees and managers aimed to identify the degree of digital maturity of an agricultural enterprise has low financial and time costs and can be carried out remotely in small organizations, which is especially important in the current epidemiological situation. The survey results can be used by digital transformation experts. A preliminary assessment of the digital maturity of an agricultural enterprise can be carried out by employees, and a detailed assessment can be carried out by consulting companies. The growth of the digital maturity of an enterprise is a complex iterative process that does not have the only correct development trajectory [4]. Therefore, the proposed methodology must be combined with other tools for analyzing the readiness for digital transformation.

\section{References}

1. Digital Agriculture, Departmental project, Official publication (Rosinformagrotech, Moscow, 2019), $48 \mathrm{p}$.

2. Methodology for assessing the digital maturity of an organization, Retrieved from: https://cpur.ru/wpcontent/uploads/2020/10/Metodologiya-oczenki- czifrovoj-zrelosti-organizaczii.pdf (Date of access: 03/05/2021)

3. Collective farm Niva, Retrieved from: https://www.rusprofile.ru/id/2030686 (Date of access: 03/05/2021)

4. T.A. Gileva, Digital maturity of the enterprise: methods of assessment and management, Bull. of USPTU, Sci., Ed., Econ., Ser. Econ., 1(27) (2019)

5. D.V. Kuzin, Problems of digital maturity in modern business, World of a new econ., 3 (2019)

6. S.A. Spornyak, Yu.S. Volvak, "Digitalization as a factor in the development of agriculture", Coll. of abstr. of part. in the pool of sci. and pract. Conf. (2021), pp. 662-664

7. A. Mironkina, S. Kharitonov, A. Kuchumov, A. Belokopytov, Digital technologies for efficient farming, IOP Conf. Ser. Earth and Envir. Sci., 012017 (2020)

8. N.A. Safiullin et al., Quality assessment of electronic state and municipal services using the example of the ministry of agriculture of the Russian Federation, BIO Web of Conf., 17, 00143 (2020)

9. G. Krupina et al., Main directions of popularization of electronc state and municipal services among rural population, BIO Web of Conf., 27 (2020)

10. Ad.U. Mentsiev, Al.U. Mentsiev, E.F. Amirova, IoT and mechanization in agriculture: problems, solutions, and prospects, IOP Conf. Ser. Earth and Envir. Sci., 548(3), 032035 (2020)

\footnotetext{
* Corresponding author: nsafiullin@outlook.com
} 